\title{
The Involvement of Local Community in Mangrove Forest Conservation in West Kalimantan
}

\author{
Emi Roslinda ${ }^{1, *}$, Lilis Listyawati ${ }^{2}$, Ayyub $^{1}$, Farih Al Fikri ${ }^{1}$ \\ ${ }^{1}$ Faculty of Forestry, Tanjungpura University. Jalan Daya Nasional, Pontianak 78124, Kalimantan Barat, Indonesia \\ ${ }^{2}$ Politeknik Negeri Pontianak. Jalan Ahmad Yani, Pontianak, 78124, Kalimantan Barat, Indonesia \\ ${ }^{*}$ Corresponding author. E-mail address: eroslinda71@gmail.com
}

\section{ARTICLE HISTORY:}

Received: 26 November 2020

Peer review completed: 12 March 2021 Received in revised form:17 March 2021 Accepted:19 March 2021

\section{KEYWORDS:}

Forest conservation Local community Mangrove
C 2021 The Authors. Published by Department of Forestry, Faculty of Agriculture, University of Lampung in collaboration with Indonesia Network for Agroforestry Education (INAFE).

This is an open access article under the CC BY-NC license:

https://creativecommons.org/licenses/bync/4.0/

\begin{abstract}
Mangrove forest conservation on the coast of West Kalimantan has been successfully carried out and saved the environment from coastal abrasion (ecological benefit) and provided economic benefits for the community. This study aims to describe the role of the community in mangrove conservation activities in the coastal areas of West Kalimantan. Survey methods were used in this research. The data was collected through interviews based on questionnaires and in-depth interviews. Data processing was conducted by calculating the percentage and then analyzed by tabulation. Mangrove conservation activities are based on community experiences in saving the environment, boosting economic activities, and obtaining benefits from conservation results. The involvement of the local community uses the bottom-up approach, starting from planning activities, implementation, utilization, and evaluation. In general, the local community's level of involvement is still at the information and consultation stage. The involvement of the local community as an individual varies greatly, from those who are only involved as part of formality to the level of being actively involved, having decision-making authority, and being able to negotiate and deal directly with capital sources. It occurs due to the varying capacity of each individual.
\end{abstract}

\section{Introduction}

Mangrove ecosystems are natural resources that have benefits and influence on various aspects of life. The magnitude of the role of the mangrove ecosystem for life can be indicated by the many types of animals and plants whose lives depend on the mangrove ecosystem. Likewise, the benefits and values of the mangrove ecosystem play a major role in human life, both direct benefits and indirect benefits (Nandu et al. 2019; Roslinda et al. 2020).

The mangrove ecosystem is a unique ecosystem on the coast, as a land protector, protecting from abrasion and seawater intrusion (Vitasari 2015). However, mangrove ecosystems are very vulnerable because they are susceptible to environmental changes (Eddy et al. 2016), originating from human and natural activities. For example, Kalimantan in 1989 had mangrove forests reaching more than one million ha, but in 2009 it decreased to the remaining 638,283 ha (Ilman et al. 2011). West Kalimantan has mangrove forests covering an area of 149,344.189 ha (Hartini et al. 2010). The mangrove forest ecosystem is spread across 7 regencies/cities, including Kubu Raya 
Regency, Mempawah Regency, Singkawang City, Bengkayang Regency, Sambas Regency, and Ketapang Regency. The types of flora that adorn the mangrove ecosystem of West Kalimantan include api-api (Avicennia sp.), perepat or pidada (Sonneratia sp.), mangroves (Rhizophora sp.), temu or kendaka (Bruguiera sp.), nyirih (Xylocarpus granatum), nipah (Nipah sp.), pandan (Pandanus amaryllifolius), and nibung (Oncosperma tigillarium).

Seeing the current conditions regarding various activities in the mangrove area, the role of the community needs to be continuously studied and developed, especially concerning the conservation of mangrove forest resources. The success of conservation with a community involvement approach has been done a lot, either through religious, cultural, or other approaches depending on the most dominant area in the area that will be used as a conservation area. Involvement starts from planning, implementation, and evaluation. The Law of the Republic of Indonesia No. 32 of 2009 on Environmental Protection and Management (Article 70 paragraph 3) states the role of the community is: (1) increasing awareness of environmental protection and management; (2) increasing independence, community empowerment, and partnerships; (3) developing the capacity and leadership of the community; (4) fostering community immediate responsiveness to carry out social surveillance; and (5) developing and maintaining local culture and wisdom in the framework of preserving environmental functions. Community involvement is strengthened, and community initiatives are encouraged in the management of mangrove ecosystems as part of coastal areas as stipulated in Article 4 (a, c, d) of Indonesian Law No. 27 of 2007 on Coastal Zone Management implemented with the aim of: (1) protecting, conserving, rehabilitating, utilize, and enrich Coastal Resources and Small Islands and its ecological systems sustainably; (2) strengthening the involvement of the community and government institutions and encouraging community initiatives in the management of Coastal and Small Islands Resources to achieve justice, balance, and sustainability; and (3) increasing the social, economic and cultural values of the community through community involvement in the utilization of coastal resources and small islands. This shows that legally the role of the community in environmental management and protection is guaranteed the legality of its activities.

The role of the community in natural resource management activities can be seen at various levels of activities carried out. The role is often known as involvement, such as community involvement in the process of identifying problems and potential in the community, selecting and making decisions about alternative solutions to dealing with issues, implementing efforts to overcome difficulties, and community involvement in the process of evaluating changes that occur (Isbandi 2007). The community involvement in an environmental management activity can be measured in various ways, such as using the involvement index from Stuart (1952), while community involvement can be measured using the involvement instrument from Arnstein (1969).

Various studies on community-based mangrove conservation have been carried out, such as in Probolinggo (Pribadiningtyas et al. 2013), Bekasi (Yuliani and Herminasari, 2017), Pesawaran (Alfandi et al. 2019), and Tiwoho, North Sulawesi (Nurrani et al. 2015). However, information regarding mangrove conservation on the coast of West Kalimantan based on the role of local communities is not yet known, so this research is needed. Seeing the current conditions regarding various activities in the mangrove area, mangroves planting by the community has given encouraging results. Several mangrove areas have been planted to the land area, such as in Desa Pasir and Mendalok Village of Mempawah Regency, and in Setapuk Besar Village of Singkawang City, proved that the community could rehabilitate the damaged mangrove land. How the community participates in managing mangroves is a problem in this study. This study aims to 
describe community involvement in mangrove conservation activities in the coastal areas of West Kalimantan.

\section{Materials and Methods}

Research locations in the mangrove areas in the West Kalimantan coast were in the mangrove area in Pasir Village, Mempawah Hilir District, Mempawah Regency, in the mangrove area in Mendalok Village, Sungai Kunyit District, Mempawah Regency, and in the Setapuk mangrove area in Setapuk Besar Village, Singkawang Utara District, Singkawang City, West Kalimantan. Three research locations were selected purposively, considering the mangrove area, which increased in size and managing by the local community. The research subjects were the people in the three research locations. The research sample was carried out by quota sampling at each site as many as 30 people, considering that it could represent the total population available for comparative research (Gall et al. 2007) and correlation research (Gay et al. 2009).

The data were collected in several ways, such as interviews using a questionnaire, in-depth interviews, and observation to see the role of the community. In-depth interviews were conducted with key informants present at the location. Involvement data measurement was undertaken by categorizing it based on the activities carried out by the respondent. The degree of community involvement was measured by the involvement instrument from Arnstein (1969). The data analysis was calculated qualitatively.

\section{Results and Discussion}

\subsection{Characteristics of Respondents}

The socioeconomic characteristics of the respondents in this study were sex, gender, age, education level, occupation, and involvement in the conservation group (Table 1).

Table 1. Characteristics of the respondents

\begin{tabular}{cllcr}
\hline No. & Characteristics & Category & $\begin{array}{c}\text { Total } \\
\text { (person) }\end{array}$ & $\begin{array}{c}\text { Percentage } \\
\text { (\%) }\end{array}$ \\
\hline 1 & Sex Gender & Male & 51 & 56.67 \\
& & Female & 39 & 43.33 \\
2 & Total & & 90 & 100.00 \\
& Age & $15-33$ & 21 & 23.33 \\
& & $34-52$ & 53 & 58.89 \\
& Total & $53-71$ & 16 & 17.78 \\
3 & Education Level & & 90 & 100.00 \\
& & Elementary School (SD) & 47 & 52.22 \\
& Total & Junior High School (SMP) & 25 & 27.78 \\
4 & Occupation & Senior High School (SMA) + & 18 & 20.00 \\
& & & 90 & 100.00 \\
& & Farmer & 15 & 16.67 \\
& & Fisherman & 22 & 24.44 \\
& & Private sector & 27 & 30.00 \\
& Total & Housewife & 24 & 26.67 \\
5 & Involvement in conservation groups & 2 & 2.22 \\
& & Others & 90 & 100.00 \\
& & Yes & 41 & 45.56 \\
& Total & No & 49 & 54.44 \\
\end{tabular}


The respondents have consisted of $56.67 \%$ male and $43.33 \%$ female. Conservation activities are not entirely carried out by males only, but the female also participates in mangrove conservation activities. The age group is grouped into 3: 15-33 years, 34-52 years, and 53-71 years. In this study, the percentage of the age group of 34-52 years was more dominant with a rate of $58.89 \%$, while the remaining $23.33 \%$ was in the $15-33$ years age group and $17.78 \%$ in the $53-$ 71 years age group. The age range of $30-50$ years is a productive age with a high enough motivation to participate in mangrove conservation. This productive age is still eager to find new information to preserve natural resources around their livelihood. This condition occurs because those in the productive age range are still able to carry out activities optimally, have the enthusiasm, and are creative to look for various businesses that can increase income to fulfill the needs of their families (Sidu 2006). Meanwhile, respondents aged 50 years and over are still participating in conservation activities due to their experiences. This is because this age group has already passed the occurrence of coastal abrasion around their residence, which causes their residence to be threatened with being washed away by the seawater.

The level of education is one measure of a person's ability to identify, formulate and solve the problems at hand. The majority of respondents $(52.22 \%)$ have graduated from elementary school education, $27.78 \%$ have graduated from junior high school, and the remaining $20.00 \%$ have graduated from senior high school and above. The level of community education has a relationship with involvement in conservation activities. Sa'adah (2015) found that the level of community education has a relationship with the development of built-in land in the land and water conservation area in Sukerojo Village, Gunungpati District in Central Java, which is 31.92\%, meaning that the higher the level of education indicated the land control of built-in the area of soil and water conservation getting much better. Even though elementary school graduates dominated the respondents in the research location, the results indicated that the community could carry out mangrove conservation activities well and had succeeded in increasing the land area in their respective work areas. This means that the government reluctantly provides adequate access space for the community and emphasizes more technical and professional reasons as barriers to community involvement can be refuted (Lund 2015; Maryudi and Krott 2012; Maryudi 2014).

Respondents' jobs were varied, consisting of $16.67 \%$ farmers, $24.44 \%$ fishers, $30 \%$ working in the private sector, the $26.67 \%$ and $2 \%$ are housewives and others, respectively. The variation of the respondent work is because the respondents were taken from all people who live in the three mangrove conservation locations, not specifically for members of the mangrove conservation group. Only $45.56 \%$ of respondents who can be attributed were involved in the group, and the remaining 54.44\% were not involved in the mangrove conservation group. Even so, people who are not involved in the group (not members of the mangrove conservation group in the research location) still participate in several mangrove conservation activities in their village. Although the number involved in the group is small, it shows that the three research locations have been formed as an institution in conservation activities. Institutions are an elemental force and determining the success of community involvement.

\subsection{History of Mangrove Conservation Area Management}

The mangrove area in Pasir Village is currently known as Mempawah Mangrove Park (MMP). Pasir Village is included in the district of Mempawah Hilir and has an area of $6,000 \mathrm{~km}^{2}$. This village has a coastline of $\pm 3 \mathrm{~km}$. Pasir Village is an area that is experiencing severe abrasion, 
so local community groups carry out mangrove forest restoration activities under the Mempawah Mangrove Conservation (MMC) group. Planting activities were started in 2012 by a group of people who cares about mangrove conservation. To date, they have succeeded in planting \pm 45 ha of terraced areas, with the number of mangroves planted during $2014-2018$ reaching 142,500 seeds. Currently, the management of the MMP ecotourism area is \pm 4 ha, with the types of mangroves planted and cared for are: Rhizophora stylosa, Rhizophora mucronata, Avicennia marina, Xylocarpus granatum, Bruguiera gymnorrhiza, Bruguiera cylindrica, Sonneratia ovata, Sonneratia alba, Kandelia candel, Nypa fruticans, Excoecaria agallocha. Community groups initiated planting activities, and some activities were facilitated by partners such as the World Wildlife Fund (WWF) West Kalimantan Program. Seeing the success of conservation carried out by the community in Pasir Village, WWF disbursed assistance for constructing a Mangrove House in 2015. At the same time, the Representative Office of Bank Indonesia West Kalimantan was also present to assist in developing tourism areas and mangrove education. In Pasir Village, MMC has formed a new forum named MMP in 2016. This forum moved linearly with the MMP Desa Pasir Awareness Group (Kelompok Sadar Wisata/Pokdarwis), which has been officially inaugurated through the Decree of the Head of the Mempawah Regency Education, Youth, Sports, and Tourism Office No. 071 of 2018.

The mangrove area in Mendalok Village has experienced severe degradation due to natural factors, like abrasion and wind. In 1997, a fisherman named Mr. Yusiran carried out mangrove planting independently to save his settlement, starting from collecting seeds, planting, and maintenance. The seeds collected were in the form of mangrove seeds from around the Mendalok Village location. Mangrove species planted including api-api (Avicennia marina), bogem (Sonneratia ovata), mangroves (Rhizophora stylosa), Xylocarpus spp., and several types of mangrove associations such as jeruju (Acanthus illicifolius), and nipah (Nypa fruticans). The planting of mangrove seedlings by Mr. Yusiran has begun to attract the attention of various parties to carry out reforestation in this area. In 2011 - 2012, the Regional Government, through its specialized agency, organized the Mangrove Forest Rehabilitation activities named Community Seed Garden (Kebun Bibit Rakyat/KBR), so several local fishermen and Mr. Yusiran have joined the "Agro Mangrove Lestari" farmer group as executors of the KBR construction. The type of mangrove seedlings held was Rhizophora stylosa Griff. In 2017, the management of Mendalok mangroves was handled by the Mendalok Village government through the Jaya Mandiri VillageOwned Enterprise (Badan Usaha Milik Desa/BUMDes), especially to manage the ecotourism of the Tanjung Pagar Mangrove Tourism Park located in Mendalok Village, Sungai Kunyit District, Mempawah Regency. The Head of Mendalok Village confirmed the management of the BUMDes through the Decree of the Head of Mendalok Village Number 8 of 2017, dated 30 November 2017. Some of the programs will be implemented by BUMDes Jaya Mandiri in the effort to manage mangrove ecotourism in Polaria Tanjung Pagar in January - June 2018. The programs consist of administrative completeness counseling, the addition of mangrove pavilions, photo spot creation, financial management counseling, construction and expansion of tourist areas, and planting of mangroves. Until now, the size of the Mendalok mangrove area successfully rehabilitated was \pm 10 ha, and currently, BUMDes is focusing on managing ecotourism Taman Polaria Tanjung Pagar, covering an area of \pm 1 ha. Activities or programs carried out in the implementation of ecotourism management are borne by the Village Budget. 
The damage to the coast in the Kelurahan Setapuk Besar inspired the formation of the selfhelp association for Mangrove Care, Surya Perdana Mandiri, on August 2, 2009, initiated by Mr. Jumadi and consists of 9 members. The association was formed to carry out planting activities in the coastal area around their residence. This condition is somewhat different from the management carried out in Pahawang Island, where the formation of associations was initiated and assisted by external parties such as non-governmental organizations (Davinsy et al. 2015; Mustika et al. 2017; Febryano et al. 2014). Currently, the self-help association for Mangrove Care Surya Perdana Mandiri is a legal entity with the Decree of the Minister of Law and Human Rights of the Republic of Indonesia Number AHU 0003000.AH.01.07. 2017 concerning the Ratification of the Establishment of the Surya Perdana Mandiri Mangrove Care Association. Planting mangrove seedlings using fixed planting has produced encouraging results for mangrove conservation in Setapuk Besar. Thousands of trees have been planted and made the coast green with mangrove trees, now it has grown to an area of \pm 30 ha and succeeded in adding $\pm 127 \mathrm{~m}$ of coastal land to the sea. Currently, the mangrove area of Setapuk Besar has various tree species such as Avicennia lanata, Avicennia marina, Rhizophora apiculata, Rhizophora stylosa, Rhizophora mucronata, Acanthus ilicifolius, Acanthus ebracteatus, Bruguiera cylindrica, Ceriops ovandra, Sonneratia case, Sonnerops, Bruguiera gymnorhiza, Nypa fruticans, Terbangvium portulacastrum, Terminalia catapa, Thespesia populnea, Hibiscus tiliaceus, Clerodendrum inerme, Sesbania sesban, Portulaca oleracea, Morinda citrifolia, Wedelia biflora indica. The results illustrated the possible differences in vegetation diversity in community-managed forests (Idris et al. 2020). On the way, the community groups carried out mangrove conservation activities accompanied by various parties such as LPS-AIR, WWF, the City Government of Singkawang, and the Marine Service. The success of planting mangroves has made the Setapuk Besar mangrove area one of the tourist destinations in Singkawang City and opened up economic opportunities for the managing community.

\subsection{Community Involvement}

The study results are based on respondents' answers in mangrove conservation in three research locations: the role in conservation activities, background in participating in conservation activities, and involvement in the stage of mangrove management activities presented in Table 2. About 90 respondents representing the community in the research locus, $73.33 \%$ have participated in mangrove conservation activities. The background of community involvement is mostly done voluntarily (63.33\%). This situation occurs because most people aware of the importance of carrying out conservation activities. After all, their direct experience of coastal abrasion threatens their residence and affects the results of community coconut plantations, meaning that there is a correlation between the benefits of conservation activities and the benefits of area protection and community economic activities. The results of conservation activities have also increased opportunities for economic activity by turning mangrove planting areas into tourist areas that many people currently visited. The results are in line with the previous study (Nilson et al. 2016), which studied conservation success in developing countries in Asia, Africa, and Latin America. The study revealed that there are three main mechanisms applied, such as (1) integration of conservation and livelihood goals (sources of income); (2) provision of benefits as a result of conservation activities and giving control to the community over resources, and (3) additional mechanism in the form of conservation education. Based on observation, conservation education was also found in the three 
research locations: the MMP area, Mendalok Mangrove area, and Setapuk Besar Mangrove area. The location has become the field schools for high school students and internship and research locations for students engaged in agriculture, forestry, fisheries, and the environment in general.

Table 2. Community involvement in mangrove conservation activities

\begin{tabular}{|c|c|c|c|c|}
\hline No. & Involvement & Category & $\begin{array}{c}\text { Total } \\
\text { (person) }\end{array}$ & $\begin{array}{c}\text { Percentage } \\
(\%)\end{array}$ \\
\hline \multirow[t]{3}{*}{1} & Participate & Have a role & 66 & 73.33 \\
\hline & & Not & 24 & 26.67 \\
\hline & & Total & 90 & 100.00 \\
\hline \multirow[t]{4}{*}{2} & Background enters & Incentive & 9 & 10.00 \\
\hline & & Volunteer & 57 & 63.33 \\
\hline & & None of both & 24 & 26.67 \\
\hline & & Total & 90 & 100.00 \\
\hline \multirow[t]{3}{*}{3} & Planning & Yes & 32 & 35.56 \\
\hline & & No & 58 & 64.44 \\
\hline & & Total & 90 & 100.00 \\
\hline \multirow[t]{3}{*}{4} & Implementation & Yes & 67 & 74.44 \\
\hline & & No & 23 & 25.56 \\
\hline & & Total & 90 & 100.00 \\
\hline \multirow[t]{3}{*}{5} & Utilization & Yes & 57 & 63.33 \\
\hline & & No & 33 & 36.67 \\
\hline & & Total & 90 & 100.00 \\
\hline \multirow[t]{3}{*}{6} & Monitoring and & Yes & 21 & 23.33 \\
\hline & Evaluation & No & 69 & 76.67 \\
\hline & & Total & 90 & 100.00 \\
\hline \multirow[t]{9}{*}{7} & Involvement level & Being involved was only a formality & 15 & 16.67 \\
\hline & (Arnstein1969) & $\begin{array}{l}\text { Being involved perfunctory because they are } \\
\text { considered helpless }\end{array}$ & 2 & 0.22 \\
\hline & & $\begin{array}{l}\text { Being involved, obtain information but are not } \\
\text { given the opportunity to discuss }\end{array}$ & 7 & 7.78 \\
\hline & & $\begin{array}{l}\text { Being involved, get information, and be able to } \\
\text { discuss but the results of the discussion are } \\
\text { considered }\end{array}$ & 9 & 10.00 \\
\hline & & $\begin{array}{l}\text { Being engage, actively discuss, but the results of } \\
\text { the discussion are only a few that are considered }\end{array}$ & 16 & 17.78 \\
\hline & & $\begin{array}{l}\text { Being actively involved and share responsibilities } \\
\text { equally }\end{array}$ & 15 & 16.67 \\
\hline & & $\begin{array}{l}\text { Being actively involved and have decision- } \\
\text { making authority }\end{array}$ & 1 & 0.11 \\
\hline & & $\begin{array}{l}\text { Being actively involved, have decision-making } \\
\text { authority, can negotiate and deal directly with } \\
\text { sources of funds }\end{array}$ & 1 & 0.11 \\
\hline & & Total & 66 & 73.33 \\
\hline
\end{tabular}

Community involvement in mangrove conservation activities starts from planning, implementing, utilizing, and evaluating activities. It shows that the conservation activities carried out are bottom-up, not from government orders or programs. Based on the history of management in the three research locations, it appears that the initiative for planting activities came from local communities living around areas experiencing coastal abrasion. After the planting activity is successful, it will attract the attention of external parties, both government and private, to support mangrove conservation activities that the community has carried out. Thaman et al. (2016) proved that $43 \%$ of community involvement in conservation activities in Portugal was ineffective because it was top-down, in contrast to the conditions in Fiji, which was carried out conservation activities with a bottom-up nature where community involvement reached $88 \%$. It is like what happened in 
conservation activities in 3 research locations; when the idea of conservation did not come from community initiatives, the conservation activities did not go as expected. However, when the community realizes the importance of saving their environment, conservation activities can run smoothly and produce success. Henceforth, this success must also receive support and encouragement from outside parties, such as the government and the private sector, by providing activities needed by the community to sustain the existing conservation program. Activities to strengthen community capacity through education, counseling, and other activities can foster community strength and independence from an economic, social, and cultural perspective.

The level of community involvement is grouped into eight levels, referring to the involvement of Arnstein (1969) as presented in Table 2. About 73.33\% of respondents who took part in mangrove conservation activities were involved in activities, starting from the category involved to the extent of getting information (24.67\%); category actively involved and able to participate in the discussion (27.78\%), and the category actively involved received responsibility had the authority to make decisions $(16.89 \%)$. Based on these results, the involvement level in the research location is still at the level of information and consultation.

The level of involvement is still at the information stage because $24.67 \%$ of the community is only involved in announcing mangrove conservation activities without following further activities to participate in discussions to implement activities. Meanwhile, $27.78 \%$ of the community has reached the consultation stage, which has participated in discussions for further activities in mangrove conservation, but it is limited to the following discussion process. In contrast, the results of the discussion have not been used for program continuation. Only $16.89 \%$ have participated in all stages of activities. However, they have succeeded in carrying out mangrove conservation. This condition is almost the same as the results of Sadono (2013), stating that community involvement in Mount Merbabu National Park management is still at the information and consultation level.

The distribution of this involvement is because the capacities of each respondent are quite diverse. Some are just ordinary people, some are members of conservation groups, and some are group leaders who have direct access to determining all decisions in conservation activities. The involvement of a person to contribute in a group varies from individual to community. It depends on ability, physique, education, skills, motivation, and interests. The communities around the conservation area generally have a low level of education and income, such as in the research locations, generally only completing elementary school. Communities willing to do conservation are driven by their motivation and potential to maintain and improve the quality of the environment in which they live. According to ICEL (2009), this is caused by (1) the proximity of the community to conservation areas, (2) the existence of factors of interest, both historical, socio-religious, ecological, and economical of the local community, and (3) the existence of concern and commitment.

\section{Conclusions}

Mangrove conservation activities are carried out based on the experience of the community to save the environment in which they are living, support economic activities and get benefits from conservation results. Community involvement is bottom-up, starting from planning activities, implementation, utilization to the monitoring and evaluation. This bottom-up involvement has succeeded in carrying out mangrove conservation activities and providing benefits to the 
community, not only conservation actors. Therefore, to carry out conservation activities in degraded areas, the local community should be involved in activities to monitor and evaluate the activities. In general, the level of community involvement is at the information and consultation stage. The level of individual community involvement varies considerably, from those involved only informality to the level actively involved, has decision-making authority, can negotiate and deal directly with sources. It happens because of the diverse capacities of each individual. However, the overall level of community involvement is actively involved and gives tangible results in mangrove conservation. Support from the government and parties concerned with environmental conservation is still needed to increase community involvement, both in individual and group capacity building and capital support, in providing necessary facilities and infrastructure by including conservation activities in development programs.

\section{Acknowledgments}

The authors acknowledge Tanjungpura University for funding this research through DIPA UNTAN 2020. The authors also tank to the people of Pasir Village, Mendalok Village, and Setapuk Besar Village, and all parties who helped carry out this research.

\section{References}

Alfandi, D., Qurniati, R., and Febryano, I. G. 2019. Community Participation in Mangrove Management. Jurnal Sylva Lestari 7(1): 30-41. DOI: 10.23960/js11730-41

Arnstein, S. R. 1969. A Ladder of Citizen Participation. Journal of the American Institute of Planners 35(4): 216-224. DOI: 10.1080/01944366908977225

Gall, M., Gall, J., and Borg, R. 2007. Educational Research: An Introduction, 8th Edition. New York, NY: Pearson Education. 936 p.

Davinsy, R., Kustanti, A., and Hilmanto, R. 2015. Study of Mangrove Forest Management in the Pahawang Island Village, Marga Punduh District, Pesawaran Regency. Jurnal Sylva Lestari 3(3): 95-106. DOI: 10.23960/js13395-106

Eddy, S., Ridho, M. R., Iskandar, I., and Mulyana A. 2016. Community-Based Mangrove Forests Conservation for Sustainable Fisheries. Jurnal Silvikultur Tropika 7(3): 43-47.

Febryano, I. G., Suharjito, D., Darusman, D., Kusmana, C., and Hidayat, A. 2014. The Roles and Sustainability of Local Institutions of Mangrove Management in Pahawang Island. Jurnal Manajemen Hutan Tropika 20(2): 69-76. DOI: 10.7226/jtfm.20.2.69

Gay, L. R., Mills, G. E., and Airasian, P. W. 2009. Educational Research: Competencies for Analysis and Applications, $10^{\text {th }}$ Edition. New Jersey: Pearson Education. $667 \mathrm{p}$.

Hartini, S., Guridno, B., Yulianto, M., and Suprajaka. 2010. Assessing the Use of Remotely Data for Mapping Mangrove Indonesia. Selected Topic for Remote Sensing in $6^{\text {th }}$ WSEAS International Conference on Remote Sensing (Remote 10). Iwate Prefectural University. Japan.

ICEL. 2009. Kajian Hukum dan Kebijakan Pengelolaan Kawasan Konservasi di Indonesia Menuju Pembangunan Desentralisasi dan Peningkatan Peranserta Masyarakat. Bogor: Indonesian Center for Environmental Law Indonesia (ICEL).

Ilman, M., Wibisono, I. T. C., and Suryadiputra, I. N. N. 2011. State of the Art Information on Mangrove Ecosystems in Indonesia. Bogor: Wetlands International - Indonesia Programme. 
Idris, M. H., Latifah, S., and Setiawan B. 2020. Vegetation Condition of Community-Managed Forests in Aik Bual Village and Setiling Village, Lombok Island. Jurnal Sylva Lestari 8(2): 218-229. DOI: $10.23960 /$ js128218-229

Isbandi, R. A. 2007. Perencanaan Partisipasi Berbasis Aset Komunitas: dari Pemikiran Menuju Penerapan. Depok: FISIP UI Press. 176 p.

Maryudi, A., and Krott, M. 2012. Local Struggle for Accessing State Forest Property in a Montane Forest Village in Java, Indonesia. Journal of Sustainable Development 5(7): 62-68. DOI:

Maryudi, A. 2014. An Innovative Policy for Rural Development? Rethinking Barriers to Rural Communities Earning Their Living from Forests in Indonesia. Jurnal Ilmu Kehutanan 8(1): 50-64. DOI: $10.22146 /$ jik.8575

Mustika, I. Y., Kustanti, A., and Hilmanto, R. 2017. Actors Interest and Roles on Mangrove Forest Management in the Pulau Pahawang Village Marga Punduh Subdistrict Pesawaran Regency. Jurnal Sylva Lestari 5(2): 113-127. DOI: 10.23960/js125113-127

Lund, J. F. 2015. Paradoxes of Participation: The Logic of Professionalization in Participatory Forestry. Forest Policy and Economics 60 :1-6. DOI: 10.1016/j.forpol.2015.07.009

Nandu, I., Roslinda, E., and Hardiansyah, G. 2019. Economic Valuation of Mangrove Areas Indirect Use Value in Setapuk Besar Village Singkawang. Jurnal Hutan Lestari 7(1): 415423. DOI: 10.26418/jhl.v7i1.32116

Nilsson, D., Baxter, G., Butler, J. R. A., Mc Alpine, C. A. 2016. How do Community-Based Conservation Programs in Developing Countries Change Human Behaviour? A Realist Synthesis. Biological Conservation 200: 93-103. DOI: 10.1016/j.biocon.2016.05.020

Nurrani, L., Bismark, M., and Tabba, S. 2015. Institution and Communities Participation in the Conservation of Mangrove/Case Study in Tiwoho Village, North Province. Wasian 2(1): 2132. DOI: 10.20886/jwas.v2i1.866

Pribadiningtyas, D. K. 2013. Society Participation Towards the Rehabilitation of Mangrove (Study about Government Roles to Improving the Society Participation for Mangrove Forest Rehabilitation in Environmental Agent at Probolinggo City. Administrasi Publik 1(3):70-79.

Roslinda, E., Rahayuni, S., and Prayoga, S. 2020. Pengelolaan dan Pemanfaatan Hasil Hutan Mangrove: Studi Kasus di Masyarakat Mendalok, Kalimantan Barat. Pros Sem Nas Masy Biodiv Indon 6(1): 564-570. DOI: 10.13057/psnmbi/m060119

Sa'adah, L. 2015. Hubungan Tingkat Pendidikan Masyarakat dengan Pengetahuan Berkembangnya Lahan Terbangun di Kawasan Konservasi Tanah dan Air Kelurahan Sukorejo Kecamatan Gunungpati. Universitas Negeri Semarang [Thesis].

Sadono, Y. 2013. Peran Serta Masyarakat dalam Pengelolaan Taman Nasional Gunung Merbabu di Desa Jeruk Kecamatan Selo, Kabupaten Boyolali. Jurnal Pembangunan Wilayah dan Kota 9(1): 53-64. DOI: 10.14710/pwk.v9i1.6526

Sidu, D. 2006. Pemberdayaan Masyarakat Sekitar Kawasan Hutan Lindung Jompi Kabupaten Muna, Provinsi Sulawesi Tenggara. [Thesis] Bogor: Sekolah Pascasarjana IPB

Stuart, C. 1952. Social Participation Scale. Minneapolis: University of Minnesota Press.

Thaman, B., Icely, J. D., Fragoso, B. D. D., and Veitayak, J. 2016. A Comparison of Rural Community Perceptions and Involvement in Conservation between the Fiji Islands and Southwestern Portugal. Ocean \& Coastal Management 133: 43-52. DOI: 10.1016/j.ocecoaman.2016.09.007

Vitasari, M. 2015. Kerentanan Ekosistem Mangrove terhadap Ancaman Gelombang Ekstrim/Abrasi di Kawasan Konservasi Pulau Dua Banten. Bioedukasi 8(2): 33-36. 
Yuliani, S., and Herminasari, N. S. 2017. Partisipasi Masyarakat dalam Pengelolaan Hutan Mangrove di Desa Segarajaya, Kecamatan Tarumajaya Kabupaten Bekasi. Green Growth dan Manajemen Lingkungan 6(2): 42-53. DOI: 10.21009/jgg.062.04 